\title{
A Study on the Remodeling Policies in South Korea
}

\author{
Haeyeon Yoo \\ Assistant Professor, School of Architecture \\ zenism@ssu.ac.kr
}

\begin{abstract}
Recently in Korea, the lack of environmental management of deteriorated residential areas has become one of the key social issues, and people are paying more attention to residential area regeneration as well as the improvement of small block-unit residential environments, although some small-sized maintenance policies and remodeling projects have been proposed so far, few studies have been conducted on programs for concrete execution. This study therefore investigates the changes in policies that have taken place for the remodeling of residential areas in Korea.
\end{abstract}

Keywords: Low-rise Residential; Residential Environment Improvement; Remodeling; Apartment; South Korea

\section{Introduction}

The 'vertically extended remodeling' project in Korea, implemented in April 25, 2014, was introduced to improve residential environments of deteriorated apartments and to reduce residents' expenses. This project was mainly aimed at ensuring the long-term durability of apartments rather than profitability. In line with this, the government subsequently attempted to promote an integrated management of apartments considering their life cycles. To achieve this management, specific administrative support measures were also provided for promoting remodeling, along with the systemic improvements. In detail, 15-story or higher-rise apartments were allowed to be built higher up to 3 additional stories and 14-story or lower-rise apartments were allowed to be extended up to 2 floors higher. Thus, the increasing rate of the existing households was eased into $15 \%$ from the existing $10 \%$ [1].

Despite such intentions, however, allowing vertical remodeling causes various concerns in terms of an increasing amount of self-pay, traffic that requires parking spaces, structural safety of buildings, blocking the sunlight in the adjacent areas, etc.

Additionally, the institutional range involved in remodeling is focused only on large-scale public housing and apartment complexes, which can also be a concern. Furthermore, timely attention is being paid to the remodeling of deteriorated row houses and multi-family houses scattered throughout the cities.

Therefore, this study was intended to obtain basic research information to suggest future housing directions by looking at the status of remodeling policies in Korea. To that end, this study attempted to derive research areas in need by examining the previous studies by keywords related to remodeling in Korea, and demonstrated recognition of the need to redirect remodeling. 


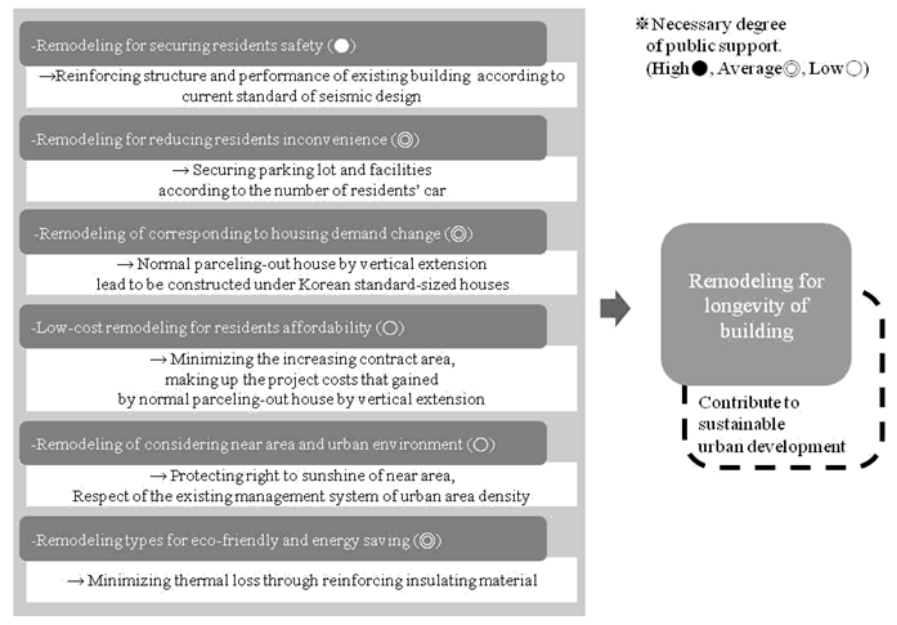

\section{Figure 1. Policy Objective and Promotion Strategy of Vertically Extended}

Remodeling Source: Young-Deok, Kim; Jun-Ho, Ko. Policy Development Guidelines on the Effect Estimation on Promoting Apartment Remodeling Policy in Seoul, 2013 p11

Despite such intentions, however, allowing vertical remodeling causes various concerns in terms of an increasing amount of self-pay, traffic that requires parking spaces, structural safety of buildings, blocking the sunlight in the adjacent areas, etc.

Additionally, the institutional range involved in remodeling is focused only on large-scale public housing and apartment complexes, which can also be a concern. Furthermore, timely attention is being paid to the remodeling of deteriorated row houses and multi-family houses scattered throughout the cities.

Therefore, this study was intended to obtain basic research information to suggest future housing directions by looking at the status of remodeling policies in Korea. To that end, this study attempted to derive research areas in need by examining the previous studies by keywords related to remodeling in Korea, and demonstrated recognition of the need to redirect remodeling.

\section{Directions of Previous Studies in Korea}

Attempts were made on keyword-based search for previous studies that are relevant to remodeling in Korea and to classify and arrange them in terms of 'policies/systems (laws), remodeling types, planning trends, practices, theories, international studies, and evaluation after residence.

As can be seen in the table below, previous studies on remodeling were focused on practices/policies and revitalization plans regarding apartments. These studies are quite necessary, considering the housing situation in Korea, which is enough to be called the 'Republic of Apartments.' These studies are also significant in that they made a contribution in reducing reconstruction /redevelopment and presented ways to regenerate deteriorated apartments.

But currently, deteriorated apartments (incl. multi-family houses, single building apartment, etc.) are accounting for about $46 \%$ of the domestic houses, as well as even single-family houses. These need to be remolded due to the problems related to cracking, condensation, environments, structure, and safety. Therefore, planning instructions and policy directions must be presented in terms of such issues.

In other words, differentiated policies and research directions should be presented without being limited to remodeling. In addition, especially for the apartment buildings, remodeling cases and statuses should be released along with the directions for improvements and plans. Additionally, empirical studies suggesting 
and applying a variety of approaches should be conducted to ensure economic and sustainable management within a range that does not increase the self-pay.

Table 1. Actual Status of Previous Studies

\begin{tabular}{|c|c|}
\hline Classification & Author (Year) \\
\hline $\begin{array}{l}\text { Case Analysis } \\
\text { Research }\end{array}$ & $\begin{array}{l}\text { Hyoung (2013); Kang (2012); Cha (2010); Choi (2006); Go et al (2006) ; Hong et al (2005); Sun et al } \\
(2003) \text {; Lee et al (2002) }\end{array}$ \\
\hline $\begin{array}{l}\text { Improvement of policy and } \\
\text { legal system }\end{array}$ & $\begin{array}{l}\text { Lee (2013); Choi (2012) ; Kim (2011); Kim (2010); Kwon. (2008); Oh et al(2008); Jeong (2007); Yoon } \\
\text { et al (2005); Moon et al (2003) }\end{array}$ \\
\hline $\begin{array}{l}\text { Analysis of Feasibility and } \\
\text { efficiency }\end{array}$ & $\begin{array}{l}\text { Yeon et al (2014); Yun et al(2012); Kim et al(2011); Kim et al(2006); Kim et al(2005); Jeong et al(2005); } \\
\text { Rhee et al(2004) }\end{array}$ \\
\hline $\begin{array}{l}\text { Planning guideline } \\
\text { Proposals }\end{array}$ & $\begin{array}{l}\text { Choe (2013); Han et al (2012); Kim (2012); Lee et al (2012); Lee et al (2011); Choi et al (2009); Byun } \\
\text { (2009); Choi (2007); Kim. (2005); Na (2003) }\end{array}$ \\
\hline Types & Kim et al (2009); Choi (2007); Eo et al (2004 \\
\hline $\begin{array}{l}\text { Trend of remodeling } \\
\text { plan (APT) }\end{array}$ & $\begin{array}{l}\text { Park et al (2011); Choi et al (2006); Lee et al (2005); Lee et al (2004); Oh et al (2004); Shin et al (2003); } \\
\text { Lee et al (2002) }\end{array}$ \\
\hline Theory & Baek et al (2012) \\
\hline $\begin{array}{l}\text { Analysis of remodeling } \\
\text { Preferences and } \\
\text { demands of residents }\end{array}$ & $\begin{array}{l}\text { Ahn et al (2013); Lim et al (2011); Choi et al (2009); Choi et al (2008); Song et al (2006); Yoon et al } \\
\text { (2006); Choi et al (2006); Shin (2005); Lee (2005); Lee (2004); Yoo et al (2004); Lee et al (2003); Lee et al } \\
(2003) \text {; Lee et al (2002) }\end{array}$ \\
\hline $\begin{array}{l}\text { Comparative study of } \\
\text { Overseas cases }\end{array}$ & Lee et al (2009); Oh.et al (2009); Yoon et al (2007); Yoon et al (2005) \\
\hline
\end{tabular}

\section{Remodeling Policy Changes in Korea}

To understand the changes in the remodeling policy of Korea, institutional changes were reviewed. The results are shown in the table below. [2]

Table 2. Change in Remodeling Legal System

\begin{tabular}{|c|c|c|}
\hline $\begin{array}{l}\text { Juridical date } \\
\text { (Enforcement } \\
\text { date) }\end{array}$ & Law & Project and Law \\
\hline $\begin{array}{l}\text { May.29. } 2003 \\
\text { (Nov.30. 2003) }\end{array}$ & $\begin{array}{l}\text { Housing act } \\
\text { All revised }\end{array}$ & $\begin{array}{l}\text { - Introducing remodeling system to the housing act. } \\
\text { - Introducing remodeling housing association system. } \\
\text { - Preparing criteria of permission. } \\
\text { - Recognizing whole and section remodeling. } \\
\text { - Revising remodeling agreed rate to } 80 \text { percent. }\end{array}$ \\
\hline $\begin{array}{l}\text { Jul.13. } 2005 \\
(\text { Jul.13. 2005) }\end{array}$ & $\begin{array}{l}\text { Housing act } \\
\text { Article } 2\end{array}$ & $\begin{array}{l}\text { - Revising term definition of remodeling (Deciding scope of vertical extension } \\
\text { by presidential Decrees). } \\
\text { - Restriction of scope of extension works for constructional safety and } \\
\text { housing environment in multi-unit dwelling. }\end{array}$ \\
\hline $\begin{array}{c}\text { Sep.16. } 2005 \\
\text { (Sep.16. 2005) }\end{array}$ & $\begin{array}{l}\text { Enforcement ordinance of } \\
\text { housing act, } \\
\text { the second of } \\
\text { article } 4 \text {, } \\
\text { attached table } 3\end{array}$ & $\begin{array}{l}\text { - Defining permission of vertical extension within one-tenth of the Exclusive } \\
\text { Dwelling Area from Presidential Decrees. } \\
\text { - Recognition of pilotis structure and permission of vertical extension at the top } \\
\text { floor. }\end{array}$ \\
\hline $\begin{array}{l}\text { Mar.16. } 2007 \\
(\text { Mar.16. 2007) }\end{array}$ & $\begin{array}{l}\text { Enforcement of } \\
\text { housing act, } \\
\text { the second of } \\
\text { article } 4\end{array}$ & 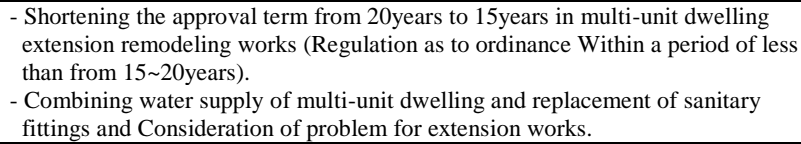 \\
\hline $\begin{array}{c}\text { Jul.06. } 2007 \\
\text { (Jul.06. 2007) }\end{array}$ & $\begin{array}{l}\text { Enforcement of } \\
\text { housing act, } \\
\text { Article } 47\end{array}$ & $\begin{array}{l}\text { - Residents who agree to remodel a building for reconstruction can withdrawal } \\
\text { agreement in writing before housing association or resident representative } \\
\text { meeting submits application for construction permission. }\end{array}$ \\
\hline $\begin{array}{c}\text { Jan.26. } 2012 \\
\text { (Jul.27. 2012) }\end{array}$ & $\begin{array}{l}\text { Housing act } \\
\text { Article 2, etc. }\end{array}$ & $\begin{array}{l}\text { - Expanding the range extension of e within } 85 \text { sqm from } 30 \% \text { to } 40 \% \text {. } \\
\text { - Permission of Increasing number of households within the extension works' } \\
\text { range (permission limited Horizontal extension, Annex building extension, } \\
\text { Generation division within } 10 \% \text { of the number of Exiting Households) except } \\
\text { for vertical extension / Creating discussion of urban plan for remodeling to } \\
\text { remodeling. }\end{array}$ \\
\hline $\begin{array}{l}\text { Dec.24. } 2013 \\
(\text { Apr.25. 2014) }\end{array}$ & $\begin{array}{l}\text { Housing act } \\
\text { Article } 2 \text {, etc. }\end{array}$ & $\begin{array}{l}\text { - Permitting vertical extension remodeling and extending scope of increasing } \\
\text { number of households( } 10 \text { percent to } 15 \text { percent ) / Inspecting security of safety } \\
\text { inspection and safety related to professional institution , preparing safety and } \\
\text { alternatives of structure of vertical extension criteria } \\
\text { - Mandated to establish the remodeling fundamental (for metropolitan city with } \\
\text { more than } 500 \text { thousand citizen) }\end{array}$ \\
\hline
\end{tabular}

Source: Ministry of Land, Infrastructure and Transport(MOLIT), Housing Redevelopment Division the current situation of improved regulation and remodeling system, February, 2014, p2 
The Korean government has improved remodeling programs for apartments by providing various measures and especially considering those being deteriorated over time. Korea has attempted to make apartment - oriented institutional changes in accordance with the housing act. Thus, the institutional changes in Korea are different from those in other countries because of their differences in terms of programs, market sizes, and support systems. [3]

Table 3. Comparison of Domestic \& Overseas Remodeling System

\begin{tabular}{|c|c|c|c|c|c|}
\hline Country & $\begin{array}{r}\text { Term } \\
\text { definition } \\
\end{array}$ & Relative regulation & $\begin{array}{l}\text { Support } \\
\text { system }\end{array}$ & $\begin{array}{l}\text { Scale of a } \\
\text { market * }\end{array}$ & $\begin{array}{l}\text { Public main } \\
\text { agent }\end{array}$ \\
\hline $\begin{array}{l}\text { Republi } \\
\text { c of Korea }\end{array}$ & Remodelin & $\begin{array}{l}\text { Architecture law } \\
\text { Housing law } \\
\text { Law of urban } \\
\text { And residential } \\
\text { environment } \\
\text { arrangement }\end{array}$ & $\begin{array}{l}\text { Incentive } \\
\text { system bounded } \\
\text { by } \\
\text { each law }\end{array}$ & $10 \%$ & $\begin{array}{l}\quad \text { Central } \\
\text { government and } \\
\text { local government }\end{array}$ \\
\hline Japan & Reform & $\begin{array}{l}\text { Conference of part of } \\
\text { government }\end{array}$ & $\begin{array}{l}\text { Reforming } \\
\text { roan system }\end{array}$ & $30 \%$ & $\begin{array}{l}\text { Housing reform } \\
\text { center, } \\
\quad \text { Urban } \\
\text { Renaissance Agency } \\
\text { (UR) }\end{array}$ \\
\hline $\begin{array}{l}\text { Singapo } \\
\text { re }\end{array}$ & Reform & $\begin{array}{l}\text { Real Estate Renewal } \\
\text { Strategy (ERS) }\end{array}$ & $\begin{array}{l}\text { subsidy of } \\
\text { cost of } \\
\text { construction }\end{array}$ & $20 \%$ & $\begin{array}{l}\text { Housing and } \\
\text { Development Board } \\
\text { (HDB) }\end{array}$ \\
\hline America & Remodelin & $\begin{array}{l}\text { National Association of } \\
\text { Home Builders } \\
\text { (NAHB) }\end{array}$ & $\begin{array}{l}\text { Roan } \begin{aligned} & \text { system } \\
& \text { of } \text { central } \\
& \text { government }\end{aligned}\end{array}$ & $30 \%$ & $\begin{array}{l}\text { Local } \\
\text { government }\end{array}$ \\
\hline England & Renovation & $\begin{array}{l}\text { Law of } \\
\text { construction and } \\
\text { reproduction }\end{array}$ & $\begin{array}{l}\text { subsidy, loan } \\
\text { of } \\
\text { government }\end{array}$ & $45 \%$ & $\begin{array}{l}\quad \text { Central } \\
\text { Government and } \\
\text { local government }\end{array}$ \\
\hline France & $\begin{array}{l}\text { Moderni- } \\
\text { zation }\end{array}$ & $\begin{array}{l}\text { City planning and } \\
\text { Ordinance }\end{array}$ & PAH & $45 \%$ & $\begin{array}{lr}\text { Agence } & \\
\text { nationale } & \text { pour } \\
\text { l'amélioration } & \text { de } \\
\text { l'habitat } & \\
\text { (ANAH) } & \\
\end{array}$ \\
\hline $\begin{array}{l}\text { German } \\
\text { y }\end{array}$ & $\begin{array}{l}\text { Moderni } \\
\text { zation }\end{array}$ & $\begin{array}{l}\text { Related law of } \\
\text { Housing Modernization }\end{array}$ & $\begin{array}{l}\text { Installment } \\
\text { and tax } \\
\text { reduction of } \\
\text { construction } \\
\text { cost }\end{array}$ & $30 \%$ & $\begin{array}{l}\text { local } \\
\text { government }\end{array}$ \\
\hline
\end{tabular}

Korea has made remodeling policies for the purpose of environmental improvements of the deteriorated residential blocks. For example, the Ministry of Land, Transport and Maritime Affairs and the Presidential Commission on Architecture Policy have selected project areas and conducted various pilot projects for those areas. These included the 'Happy House' project, which is a residential service support center for the existing houses including the single-family houses.

This project was not a detailed practical alternative, where the income group or the amount was limited, unlike the S-Habit, which is the Seoul-typed house repair project. However, it was a policy aimed at getting people out of the standardized residential culture, centered on the apartment buildings. In other words, this policy was an alternative to improve residential environments of the existing houses and to reduce management costs. [4] 
Table 4. The Contents of Demonstration Project "Happy House"

\begin{tabular}{|c|c|}
\hline $\begin{array}{l}\text { Business } \\
\text { purposes }\end{array}$ & $\begin{array}{l}\text { - Realization of green-growth by improving house energy-efficiency of public lead } \\
\text { - Improving houses and reducing management expense of living space of existing } \\
\text { houses } \\
\text { - Retaining housing safety and improving houses for low-income household like } \\
\text { occupants of the rental housing and so on. }\end{array}$ \\
\hline $\begin{array}{l}\text { Business } \\
\text { contents }\end{array}$ & $\begin{array}{l}\text { - Providing consulting about inspecting and improving energy performance for } \\
\text { saving heating and cooling energy cost by improving energy-efficiency of existing } \\
\text { houses } \\
\text { - Providing emergency service of water lick, electrical short, freeze and burst and so } \\
\text { on. } \\
\text { - Providing service of replacing and repairing fittings, electricity, bathroom and so on. } \\
\text { - Installation of security camera in the area which lacks prevention of crime. } \\
\text { organization parks and amusement facilities, Implementing and considering green } \\
\text { business of village } \\
\text { - Connecting housing welfare businesses like welfare service, revitalization of village } \\
\text { that local government implement for low-income group to be the base of housing } \\
\text { welfare delivery system }\end{array}$ \\
\hline $\begin{array}{l}\text { Manage } \\
\text { me } \\
\text {-nt } \\
\text { method }\end{array}$ & $\begin{array}{l}\text { - Public officials or Related Specialists reside in 'Happyhouse' like apartments } \\
\text { management office }\end{array}$ \\
\hline $\begin{array}{l}\text { Burden } \\
\text { of } \\
\text { expenses }\end{array}$ & - Free-replacement or burdening only cost of materials to beneficiary \\
\hline \multirow{2}{*}{$\begin{array}{l}\text { Demonst } \\
\text { ration } \\
\text { projects } \\
\quad \text { area }\end{array}$} & $\begin{array}{l}\text { [Selection Method] } \\
\text { - Constituting evaluation committee and screened by Presidential Commission on } \\
\text { Architecture Policy(PCAP) and Ministry of Land, Infrastructure and } \\
\text { Transport(MOLIT), Selecting } 2 \text { area } \\
\text { - Evaluated on the basis of housing type(detached house regions with low apartment } \\
\text { ratio), residents characteristic(regions with coexisting low-income people and middle- } \\
\text { income people), interest and will of head of the local government, level of support of } \\
\text { regional local governments, participation of residents and civil society organization and } \\
\text { so on. }\end{array}$ \\
\hline & $\begin{array}{l}\text { [Incentive] } \\
\text {-District of demonstration projects: connecting and supporting new renewable } \\
\text { energy budget of ministry of knowledge economy } \\
\text { - Henceforward, Having priority over security of budget of Green-home business of } \\
\text { Ministry of Land, Infrastructure and Transport (MOLIT) and home improvement } \\
\text { business for the vulnerable families } \\
\text { - Planned to connect and support building retrofit project, business of repairing house } \\
\text { (S-Habitat), by Seoul government }\end{array}$ \\
\hline
\end{tabular}

Source : H. Y. Yoo, A Planing Study of Small-Unit Low-Rise Residential Block for the Urban Regeneration, Ph.D, Seoul National University, Seoul (2010), pp.65

This project was designed as a core program of the New Hou sing Movement that had been promoted by the Presidential Commission on Architecture Policy since 2010. This project was a community-based program to provide services for supporting the residents'living environment. 
Table 5. Business Contents and Target of Policy

\begin{tabular}{|c|c|c|c|}
\hline $\begin{array}{l}\text { Classificat } \\
\text { ion }\end{array}$ & $\begin{array}{c}\text { Service of energy } \\
\text { efficiency improvement in } \\
\text { housing }\end{array}$ & $\begin{array}{l}\text { Service of maintenance } \\
\text { in housing }\end{array}$ & $\begin{array}{l}\text { Housing welfare service } \\
\text { (including project of } \\
\text { revitalization of village) }\end{array}$ \\
\hline \multirow{2}{*}{$\begin{array}{l}\text { Business } \\
\text { contents }\end{array}$} & $\begin{array}{l}\text { - Providing energy } \\
\text { performance test and } \\
\text { consulting about } \\
\text { improvement scheme } \\
\text { - Inspecting insulation } \\
\text { performance of wall, } \\
\text { fittings and so on. } \\
\text { - Showing repair } \\
\text { method of finishing } \\
\text { materials. } \\
\text { - Investigating } \\
\text { mechanical efficiency in } \\
\text { change period. }\end{array}$ & $\begin{array}{l}\quad \text { - Emergency service } \\
\text { and services of technical } \\
\text { support and security of } \\
\text { replacement repair and so } \\
\text { on. : Emergency service } \\
\text { of water lick, electrical } \\
\text { short, freeze and burst } \\
\text { and so on, Consulting } \\
\text { about broken and decrepit } \\
\text { facilities, Inspecting } \\
\text { security of gas and } \\
\text { electricity. } \\
\quad \text { *Installing security } \\
\text { camera in the area which } \\
\text { lacks prevention of crime. }\end{array}$ & $\begin{array}{l}\quad \text { - Providing united } \\
\text { basic preparation plan for } \\
\text { delivery system of } \\
\text { housing welfare by } \\
\text { connecting housing } \\
\text { welfare business } \\
\quad \text { : Connecting free } \\
\text { maintenance welfare } \\
\text { service of low-income } \\
\text { group that local } \\
\text { government, civic group, } \\
\text { private enterprise provide. }\end{array}$ \\
\hline & $\begin{array}{l}\text { - Improvement for low- } \\
\text { energy green house } \\
\quad \text { : Green-Home(Ministry } \\
\text { of Land, Infrastructure and } \\
\text { Transport) } \\
\quad \text { : Connecting cost } \\
\text { supports program about } \\
\text { new renewable } \\
\text { energy(Ministry of } \\
\text { Knowledge Economy) } \\
\quad \text { : Showing related policy } \\
\text { and information on } \\
\text { material performance, } \\
\text { standard plan and so on. }\end{array}$ & $\begin{array}{l}\text { - Providing database } \\
\text { of maintenance service } \\
\text { information } \\
\quad \text { : Building database } \\
\text { about standard } \\
\text { information (such as } \\
\text { materials cost, } \\
\text { maintenance cost and so } \\
\text { on) and providing } \\
\text { information, Suggesting } \\
\text { standard drawing of } \\
\text { (drawing and } \\
\text { specification of) repair } \\
\text { Work. }\end{array}$ & $\begin{array}{l}\text { - Revitalization of } \\
\text { village such as vitalizing } \\
\text { community, supporting } \\
\text { programs and so on. } \\
\text { : Supporting } \\
\text { companion, cultural } \\
\text { class, etc. } \\
\text { Organizing parks and } \\
\text { amusement facilities. } \\
\text { Building and operating } \\
\text { 'Happy House' homepage } \\
\text { : Showing and } \\
\text { consulting related system. }\end{array}$ \\
\hline $\begin{array}{l}\text { Beneficiar } \\
\mathrm{y}\end{array}$ & $\begin{array}{l}\text { - Housing residents } \\
\text { (ultimately, general } \\
\text { public) } \\
\text { - Providing service for } \\
\text { physical housing }\end{array}$ & $\begin{array}{l}\text { Householders, } \\
\text { Ultimate community }\end{array}$ & $\begin{array}{l}\text { Owned housing group } \\
\text { like low-income group and } \\
\text { occupants of the public } \\
\text { rental housing (ultimately, } \\
\text { community) }\end{array}$ \\
\hline Offerer & $\begin{array}{l}\text { Korea Land \& Housing } \\
\text { Corporation (LH), } \\
\text { Ministry of Land, } \\
\text { Infrastructure and } \\
\text { Transport (MOLIT), } \\
\text { Ministry of Knowledge } \\
\text { Economy }\end{array}$ & $\begin{array}{l}\quad \text { Korea Land \& Housing } \\
\text { Corporation (LH), Private } \\
\text { development sectors }\end{array}$ & $\begin{array}{l}\text { Ministry of Land, } \\
\text { Infrastructure, and } \\
\text { Transport (MOLIT), Local } \\
\text { Government, Civic Group, } \\
\text { Private Enterprise, etc. }\end{array}$ \\
\hline
\end{tabular}

Source: H. Y. Yoo, A Planing Study of Small-Unit Low-Rise Residential Block for the Urban Regeneration, Ph.D, Seoul National University, Seoul (2010), pp.66-68

It was aimed at extending the culture of residential service for apartments to the single-family houses in order to improve energy efficiency, reduce management costs, and improves housing environments. After screening the applications from nationwide, the Ministry of Land, Transport and Maritime Affairs 10) selected 3 regions including Inhoo 2-dong, Jeonju, Jeonbuk (Oct. 2009); Seongsan 1-dong, Seoul (Feb. 2010); and Pyeongri 3-dong, Daegu (Feb. 2010). The ministry embarked on the project starting in Jeonju. A website became publically available, following an opening ceremony to introduce the 'Happy House' pilot project by announcing the districts that were selected for the project. This website provides information 
about the center, ways to apply for the services, details about the service contents, boards to request services, and simple ways to repair houses. It has been constantly updated to ensure that people, including the residents in the pilot project areas, can browse through the policies with ease. But for most of the pilot project districts, the communities had already become active on their own, and thus the partial development to improve residential environments has been done. For that reason, it might be difficult to gauge the realistic possibility of implementing the project in the districts. Additionally, the range of districts was quite wide, where the pilot project was applied, so more discussion is underway over the validity that one 'Happy House' can only provide the support for about 3,000 households. In addition, costs are incurred for maintenance and repair, and the fund for residential environment improvement is offered but through loans; this raises questions whether the fund can be actively utilized. [5]

For another example, the Seoul city government has been recruiting applicants for the "long-term relief houses for support of remodeling" since April 9, 2014, which is backed up with 10 million won. This remodeling project is quite significant, because it features facilities-oriented improvements on energy efficiency and structural performance as follows: waterproofing constructions for roofs, walls, and basements; internal and external insulation work; windows and doors work; and boiler, water, and sewage pipe replacement. But the project has limitation in the number of the applicants. This means that the qualification is limited to only 30 private-owned houses that are aged over 15 years, with the charter deposit of less than 80 million won, and the size of less than $60 \mathrm{~m}^{2}$. Thus, the program is quite incomplete for now. [6]
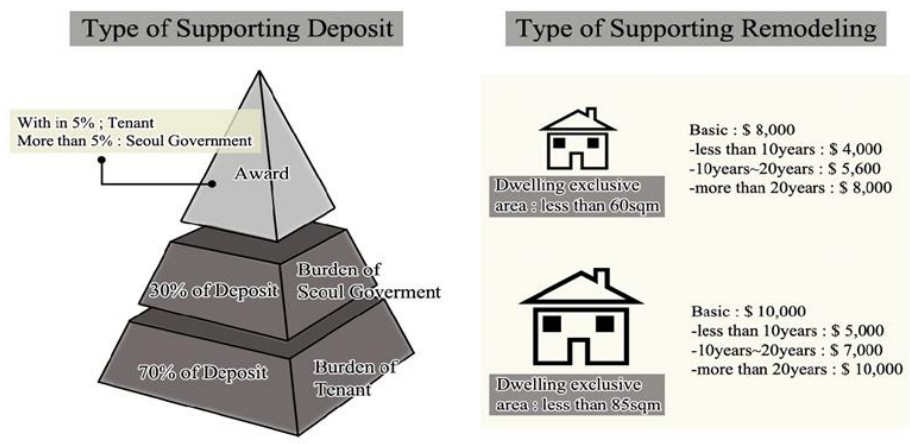

Figure 2. Diagram of Long-term Relief Houses for Support of Remodeling

Source: K. Y. Bae, Seoul city government, Long-term Relief Houses for Support of Remodeling, Asia Economy, Feb.20. (2012)

Other projects include the 'rural village remodeling project', which is not associated with urban centers. It is intended to improve the quality of life for the rural residents and to build sustainable rural communities by improving the design of poor residential environments and deteriorated houses. To support this, the Ministry of Agriculture, Food and Rural Affairs enacted and promulgated the 'Special Law for Improvement of Residential Environments and Promotion of Remodeling for Rural Villages' in June 2013. Subsequently, the ministry also established the institutional framework as the law came into force as of June 5, 2014. However, the number of the pilot project districts is limited to 4 . For the expenses, 3.9 billion won was allocated to each district, out of the total expense of 15.6 billion won. (Grants: 8.1 billion, provincial budgets; 3.5 billion, burden on borrowers; 4.1 billion) 


\section{Remodeling Policy Trends in Foreign Houses}

Foreign cases were reviewed to specifically understand the recent trends of remodeling policies for deteriorated houses in the foreign countries. In Hong Kong, the government is preparing new regeneration policies led by URA (Urban Renewal Authority) in accordance with the '4R Strategies', including Redevelopment, Rehabilitation, Reservation, and Revitalization. The government has suggested a comprehensive regeneration strategy to improve on the social environments as well, by breaking from the past 'redevelopment' approach that had focused only on the physical environment through identifying people's actual residence status and providing the appropriate 'tailored' welfare services.

In particular, the Hong Kong government has recommended housing regeneration in order to contribute to the improvement of urban environments, as well as job creation in the construction sector through the OBB (Operation Building Bright) system. The project is classified into two categories; one case is when building owners societies apply for regeneration (Category 1) and the other case is when URA (Urban Renewal Authority) or HS (Hong Kong Special Administrative Region) specifies buildings, for which the owners cannot organize a regeneration union or which they have no ability to repair. For the buildings corresponding to Category 1, the government supports owners unions to repair their building by offering them governmental grants. URA and HSG allocate the grants, while managing and supervising the buildings being repaired. As a result, a total of 1,025 buildings were selected. For the buildings classified into Category 2, the Ministry of Construction examines the buildings recommended by the city council and the city assembly, and the executive committee finally selects the structures to be repaired with URA and HS. However, if the owners' union fails to comply with the relevant instructions, the Ministry of Construction will designate a construction operator who will process the repair work on behalf of the owner union. The amount exceeding the predetermined amount of support is then received from the owner union after the construction is complete. In the case of this project, a total of 903 buildings were selected in 2011. This system has greater implications in that the government took a more active attitude than URA in actively providing subsidies to remodel deteriorated apartments or individual buildings.[7]

Recently, Japan has also shown a similar pattern. As the rate of the generation is increased by approximately $37.9 \%$ including the elderly among the socially disadvantaged, policies for the elderly people have been most actively operating compared to other policies. This project has been separately applied to individual cases as follows: one case is when the programs and projects are provided at the national level for the socially disadvantaged people; another case is when the programs or practice of projects are independently equipped by municipalities; and the other case is when auxiliary supports for national projects are offered by municipalities. This project provides a variety of housing assistance criteria and remodeling standards by considering residents' annual income. Programs supported by the central government and local governments mostly have targeted the elderly and the disabled. For the foreigners, the child-rearing generation, single-parent households, victims of domestic violence, homeless people, etc., local governments have been providing differentiated support. [8] In addition, they have established various remodeling policies to reflect the needs and natures of various consumers, which include DYI Housing, Design Select Housing, etc. [9] 
Table 6. Ma-i-yu-du Tamadayiranomori (ゆいま〜る多摩平の森)

\begin{tabular}{|c|c|c|c|}
\hline $\begin{array}{l}\text { Name of } \\
\text { company }\end{array}$ & $\begin{array}{l}\text { Co. Community } \\
\text { net }\end{array}$ & Target & Multiplex houses for aged person \\
\hline $\begin{array}{l}\text { Business } \\
\text { method } \\
\text { (lease period) }\end{array}$ & $\begin{array}{l}\text { Skelton (S) } \\
\text { leasing type } \\
\text { (20yrs) }\end{array}$ & $\begin{array}{l}\text { Date of } \\
\text { Completi } \\
\text { on }\end{array}$ & September. 2011 \\
\hline $\begin{array}{l}\text { The number } \\
\text { of buildings } \\
\text { (The number } \\
\text { of units) }\end{array}$ & $\begin{array}{l}2 \text { buildings } \\
\text { (64Units) }\end{array}$ & $\begin{array}{l}\text { Main } \\
\text { facility }\end{array}$ & $\begin{array}{l}\text { Rental houses for aged person } 32 \\
\text { (Units) } \\
+ \text { Community houses ( } 31 \text { units) } \\
\text { Small scale and multi-functional care } \\
\text { facility, Restaurant, etc }\end{array}$ \\
\hline $\begin{array}{l}\text { Construction } \\
\text { costs } \\
\text { (Fund raising) }\end{array}$ & \multirow{2}{*}{\multicolumn{2}{|c|}{$\begin{array}{l}¥ 550 \text { million } \\
\text { (Owner's capita l+ Related fund) } \\
\text { Recovery of initial investment } \\
\text { costs by collectively pre-paying } \\
\text { tenant's costs }\end{array}$}} & \\
\hline $\begin{array}{l}\text { Business } \\
\text { contents }\end{array}$ & & & \\
\hline
\end{tabular}

Source : J. D. Yoon., Establishment of Strategy for developing housing business according to changing environment, Hanglim, Seoul, pp.5-8 (2010)

In the case of New Zealand, demand for remodeling has also been growing. Auckland, for example, has attempted another transformation through the urban redevelopment from the $1960 \mathrm{~s}$. For urban areas, the city has created a bed town on its suburbs to cope with an influx of the population, which is constantly increasing with international levels of modernization. The Takapuna district in the northern suburb of Auckland and the Manukau district in the southern outskirt of Auckland are a typical residential satellite created thereof. However, recently leaky and aging phenomena, insulation related to abnormal weather, etc. have been highlighted as a problem in old rental houses of New Zealand. In addition, for the insufficient housing land caused by governmental regulations and designated conservation areas, the conflict between the government and the private sector over the number of houses, financial independence, etc. are becoming a problem. In these situations, the government has recommended old rental houses to be re-drawn, to create new drawings due to illegal modifications, insufficient data, and problematic areas to be remodeled. Such a typical example includes municipalities' recommendation of public rental houses, which are aged more than 50 years, to be re-drawn using CAD as shown below. Their efforts to prepare a policy on the remodeling direction are especially according to insulation, leaks, cracks, etc. [10] 

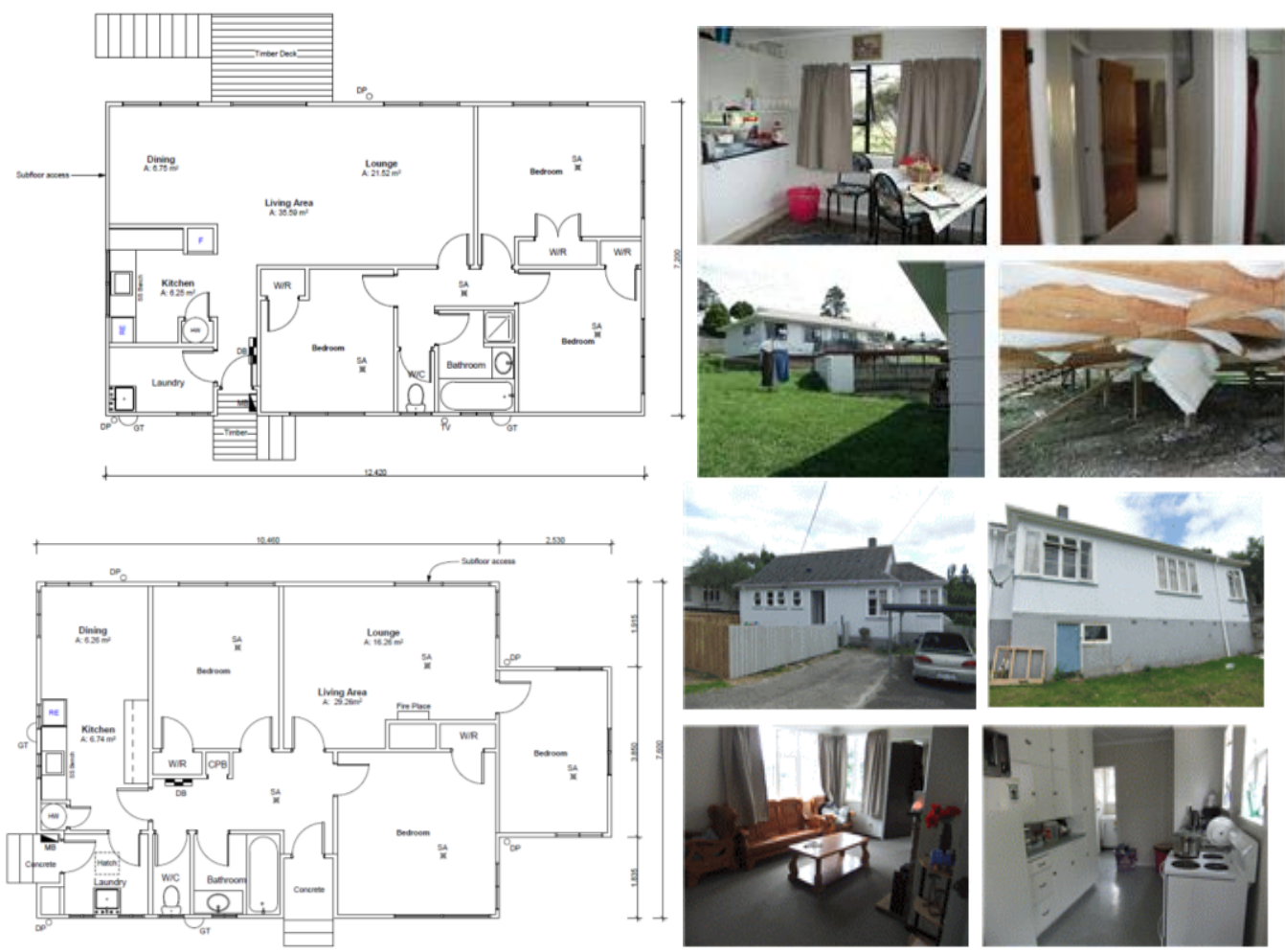
Figure 3. Document and Photos of Public housing in Auckland, New
Zealand

Source: Photo by Author, March 2014

\section{Conclusion: Necessity for Shifting Remodeling Policies in Korea}

For Korea, a representative example of vertically-extended remodeling is the 'Yega Classic' apartment complex. This apartment complex was completed in 1989, but it was remodeled in December 2012. The existing 10-story buildings were built to be extended up to 2 stories higher, and they were turned into a 12 -story building. The owners of the existing $1^{\text {st }}$ floor-apartment were allowed to use the $3^{\text {rd }}$ floorapartment, and the owners of the existing $10^{\text {th }}$ floor-apartment were able to move into a $12^{\text {th }}$ floor-one. As a result, all of the households have secured the right to view Han River from their apartment homes. In the case of the $5^{\text {th }}$ Maeul Hansol apartment complex in Sungnam, a safety inspection for vertically extended remodeling was conducted for the first time in Korea since the 2014 housing act was amended. These may be the significant cases without a doubt, since residential satisfaction with deteriorated apartments was increased and the first step toward a vertically expanded-remodeling project was taken. However, as previously stated in the introduction, problems and structural (infra) limitations associated with apartment remodeling must be solved, regardless of the benefits from a higher quality of residential environments. 

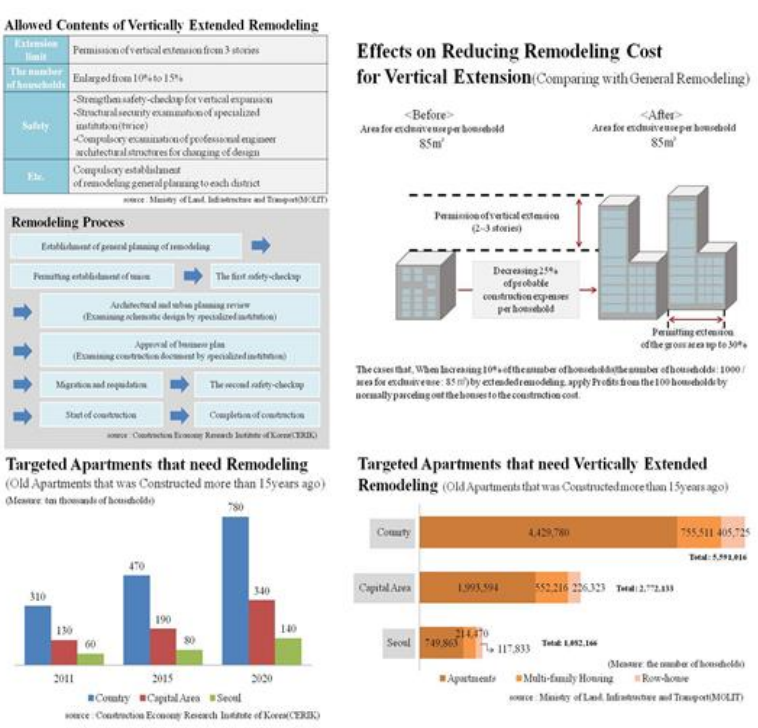

Figure 4. Remodeling System and Process in South Korea

Source: Ministry of Land, Infrastructure and Transport (MOLIT), Feb. 2015

Additionally, various other issues must be addressed regarding structural safety, utilization of environmentally friendly building materials, making the best use of the UB system for bathrooms and dressing rooms, shortening construction period, seeking sustainable management plans, linking urban infrastructures with surrounding residential facilities, considering residential environments, etc. In addition, the necessity for remodeling policies for urban apartments (town houses, multi-family houses, etc.) of less than 5 stories should be raised. Even though the government may not be engaged in both small apartments and rental houses for individuals block unit - remodeling policies need to be provided for block housing areas with apartments of less than 5 stories. [10] Also, efforts in the municipal level should be made to improve housing conditions by establishing materialized local remodeling policies. These efforts aim to prevent illegal buildings in deteriorated residential blocks from being legalized and to raise the resettlement of the native residents, all of which will play a great role in maintaining the urban views. In the current situation, new construction projects are centered on apartment building in Korea, such as new town projects, and reconstruction/redevelopment projects are being cancelled. Therefore, various in-depth studies should be conducted on remodeling plans and policies.

\section{Acknowledgements}

This work was supported by the National Research Foundation of Korea (NRF) Grant funded by the Korean Government (No.NRF-2015R1A1A3A04001377). 


\section{References}

[1] Y. D. Kim and J. H. Ko, "Policy Development Guidelines on the Effect Estimation on Promoting Apartment Remodeling Policy in Seoul, the Seoul Institute", Seoul, (2013), pp. 11.

[2] "Ministry of Land, Infrastructure and Transport (MOLIT), Housing Redevelopment Division the current situation of improved regulation and remodeling system", MOLIT Publishers, Seoul, (2014).

[3] J. A. Lee, "A Study on the Characteristics and Present Condition of Remodeling and Roan System of Central Government in Apartment Houses", KB financial holing management institute, Seoul, (2013).

[4] H. Y. Yoo, “A Planing Study of Small-Unit Low-Rise Residential Block for the Urban Regeneration”, Ph. D, Seoul National University, Seoul (2010), pp. 65.

[5] H. Y. Yoo, "A Planing Study of Small-Unit Low-Rise Residential Block for the Urban Regeneration”, Ph. D, Seoul National University, Seoul (2010), pp. 66-68.

[6] K. Y. Bae, "Seoul city government, Long-term Relief Houses for Support of Remodeling”, Asia Economy, (2012) February 20.

[7] H. Y. Yoo, Y. E. Lee and S. W. Kim, "A Study on the Government's Roles and Grant Programs for Urban Regeneration in Hongkong", Journal of the Korean Regional Development Association, Daejeon vol. 23, no. 3, (2011), pp. 59-90.

[8] H. Y. Yoo and H. Y. Yoon, "A Study on the Supporting System of the Public Rental Housing in Japan", Journal of Architectural Institute of Korea, Seoul, vol. 30, no. 1, (2014), pp. 3-12.

[9] J. D. Yoon, "Establishment of Strategy for developing housing business according to changing environment", Hanglim, Seoul, (2010), pp. 5-8.

[10] H. Yoo, "The Sustainable Remodeling Polices in South Korea”, Remodeling Report (unpublished), The Korean Housing Association, Seoul, (2015).

[11] H. Yoo, "SERSC, the Sustainable Remodeling Polices in South Korea", Proceedings of the Advanced Science and Technology Letters (ASTL), Current Research on Material, Architecture, vol. 100, (2015) August 19-21, Jeju, South Korea.

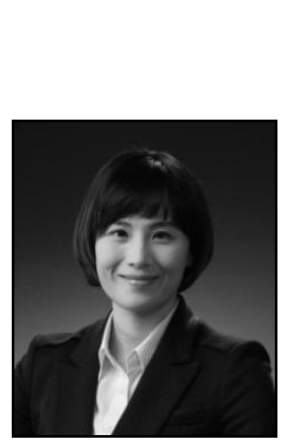

\section{Author}

Dr. Haeyeon Yoo, was born in South Korea in 1978, where she studied architecture and practiced. She did postgraduate work at SAMOO Architecture \& Engineers, Seoul, South Korea (2000 2008), and was awarded an M.A. and a Ph.D. by the Seoul National University (2006/2010). She was a senior researcher in the Korea Urban Regeneration Center of Land \& Housing Corporation in Korea (2010 2012). She has taught at universities in Kyunggi, Cheonan and Seoul. In February 2012, she became an Assistant Professor of Soongsil University's School of Architecture, where she has taught the Urban Housing Policies \& Design and Neighborhood Regeneration Program (Undergraduate Programs). 